\title{
Production and characterization of alginate-starch-chitosan microparticles containing stigmasterol through the external ionic gelation technique
}

\author{
Gislene Mari Fujiwara ${ }^{1}$, Ranieri Campos ${ }^{1}$, Camila Klocker Costa ${ }^{1}$, Josiane de Fátima Gaspari \\ Dias$^{1}$, Obdulio Gomes Miguel ${ }^{1}$, Marilis Dallarmi Miguel${ }^{1}$, Francisco de Assis Marques², \\ Sandra Maria Warumby Zanin ${ }^{1, *}$
}

\author{
${ }^{1}$ Department of Pharmacy, Federal University of Paraná, Curitiba, PR, Brazil, ${ }^{2}$ Department of Chemistry, \\ Federal University of Paraná, Curitiba, PR, Brazil
}

\begin{abstract}
Stigmasterol - a plant sterol with several pharmacological activities - is susceptible to oxidation when exposed to air, a process enhanced by heat and humidity. In this context, microencapsulation is a way of preventing oxidation, allowing stigmasterol to be incorporated into various pharmaceutical forms while increasing its absorption. Microparticles were obtained using a blend of polymers of sodium alginate, starch and chitosan as the coating material through a one-stage process using the external gelation technique. Resultant microparticles were spherical, averaging $1.4 \mathrm{~mm}$ in size. Encapsulation efficiency was $90.42 \%$ and method yield $94.87 \%$. The amount of stigmasterol in the oil recovered from microparticles was $9.97 \mathrm{mg} / \mathrm{g}$. This technique proved feasible for the microencapsulation of stigmasterol.
\end{abstract}

Uniterms: Stigmasterol/ microencapsulation. Microencapsulation. Sodium alginate/drugs coating. Chitosan/drugs coating. Starch/drugs coating. Natural polymers/drugs coating.

O estigmasterol, um fitoesterol com diversas atividades farmacológicas, é suscetível à oxidação quando exposto ao ar, calor e umidade. Neste contexto, a microencapsulação é uma forma de proteção contra oxidação, permitindo a incorporação do estigmasterol em diversas formas farmacêuticas e aumentar sua absorção. As micropartículas foram obtidas por gelificação iônica externa, em uma etapa, utilizando como revestimento polímeros naturais de alginato de sódio, amido de milho e quitosana. As micropartículas apresentaram formato esférico com tamanho aproximado de 1,4 $\mathrm{mm}$. O rendimento foi de 94,87\% e a eficiência média de encapsulação de $90,42 \%$. A quantidade de estigmasterol no óleo recuperado das micropartículas foi de $9,97 \mathrm{mg} / \mathrm{g}$. O método mostrou-se viável para a microencapsulação do estigmasterol.

Unitermos: Estigmasterol/microencapsulação. Microencapsulamento. Alginato de sódio/revestimento de fámacos. Quitosana/revestimento de fámacos. Amido/revestimento de fámacos. Polímeros naturais/ revestimento de fámacos.

\section{INTRODUCTION}

Phytosterols are triterpenes closely resembling cholesterol in both structure and function (Fernandes, Cabral, 2007; Marangoni, Poli, 2010). Many studies have demonstrated their ability to reduce serum cholesterol levels. Moreover, phytosterols present anti-inflammatory

\footnotetext{
*Correspondence: S.M.W. Zanin. Departamento de Farmácia, Universidade Federal do Paraná. Avenida Prefeito Lothário Meissner, 632, 80210-170 Curitiba - PR, Brasil. Email: sandrazanin@ufpr.br
}

(Gomez et al., 1999; Moghadasian, 2000; Gabay et al., 2010), antinociceptive (Santos et al., 1995), antiatherogenic (Marangoni, Poli, 2010) and anti-diabetic activities (Panda et al., 2009). Epidemiologic and experimental studies also suggest that phytosterols may offer protection from some types of cancers, such as colon, breast and prostate cancer (Nórmen et al., 2001; Ifere et al., 2009).

Due to their chemical structure, phytosterols are poorly absorbed by the human body, and are subject to oxidation when exposed to air. This oxidation process is 
enhanced by heating, exposure to light and by chemicals and enzymes, and can occur during cooking, food or medicine production or upon long-term storage (Lampi et al., 2002; Säynäjoki et al., 2003; Foley et al., 2010). The most common oxidation mechanism for sterols is autoxidation by triplet oxygen $\left({ }^{3} \mathrm{O}_{2}\right)$, a free radical reaction that starts with the abstraction of reactive allylic hydrogen at $\mathrm{C}_{7}$ (García-Lattas, Rodríguez-Estrada, 2011). The main oxidation products are hydroxyl, keto, epoxy and triol derivatives, all of which are polar products (Lampi et al., 2002; García-Lattas, Rodríguez-Estrada, 2011).

Many natural sterols are unsaturated $\left(\operatorname{mostly} \Delta^{5}\right)$ and are conveniently designed as stenols while their saturated analogues are called stanols (Brooks, 1970; Brufau, Canela, Rafecas, 2008). Sterols can be quantified by the colorimetric Liebermann-Burchard reaction (Wall, Kelley, 1947; Sabir et al., 2005), which is positive with stenols and negative with stanols (Brooks, 1970).

The medium in which phytosterol is dissolved has been shown to play an important role in the speed and mechanism of the formation of its oxidation products (Rudzinska et al., 2004) where pure sterols are oxidized to a greater extent than sterols contained in unsaturated and saturated matrices (Lampi et al., 2002; Otaegui-Arrazola et al., 2010).

The usual approach to minimizing oxidation is by the addition of antioxidants and also through a more recently introduced technical procedure to protect sensitive oil called microencapsulation (Velasco, Dobarganes, Márquez-Ruiz, 2000; Fernandes, Cabral, 2007).

Microencapsulation can be defined as the entrapment of a compound or a system inside a dispersed material for its immobilization, production, controlled release, structuration and functionalization. This process can be employed in many industrial and scientific domains, such as pharmaceutical, cosmetic and food industries (Poncelet, 2006).

The products resulting from microencapsulation are called microparticles, microspheres or microcapsules, differing in morphology and internal structure (Pereira et al., 2006; Jyothi et al., 2010).

Drugs are encapsulated for taste and odor masking, improvement of gastrointestinal tolerance, controlled release after oral administration and oxidative protection (Ribeiro et al., 1999; Chan, Lim, Heng, 2000; Tan, Chan, Heng, 2009).

The choice of encapsulation material and process is governed by three main criteria: the application, economics and safety. Biocompatible and biodegradable materials are preferable for use in microparticle production for medicines, food and pesticides products (Chan, 2011)
Some encapsulation methods involve organic solvents or other reagents that are incompatible with many biological encapsulants. Solvents are toxic thereby limiting widespread applicability, whereas vitamins, hormones and unsaturated aliphatic compounds are important examples of heat or oxygen labile products (Ribeiro et al., 1999; Schoubben et al., 2010).

$\mathrm{Ca}$-alginate beads represent one of the most widely used carriers and the success of this simple encapsulation method is largely due to the mild conditions needed and the low cost of the process (Fundueanu et al., 1999; Florczyk et al., 2011).

Alginate, a polymer which occurs naturally in brown algae, is a linear 1,4 linked copolymer of $\beta$-D-mannuronic acid (M) and $\alpha$-L-guluronic acid $(\mathrm{G})$ residues in varying proportions, order and molecular weights (Thu et al., 1996; Segato, 2007). It exhibits mucoadhesion (Tu et al., 2005; Wittaya-areeku, Kruenate, Prahsarn, 2006; Rowe, Sheskey, Quinn, 2009), biocompatibility, biodegradability (Lee et al., 2006; Florczyk et al., 2011), immunogenicity, thickening properties and the ability to form gels in the presence of multivalent ions (Florczyk et al., 2011).

Thus, an alginate solution is transformed into a hydrogel in the presence of divalent cations such as $\mathrm{Ca}^{+2}$ and $\mathrm{Ba}^{+2}$ (Simpson et al., 2004). The hydrogel is formed due to the interaction between guluronic residues and divalent cations, yielding a three-dimensional network of alginate filaments which are held together mainly by ionic interactions (Lee et al., 2006; Reis et al., 2006).

The resultant network depends on the frequency and length of guluronic acid residue sequence as well as the concentration and type of cation. Alginates having a high guluronic acid content develop stiffer, more porous gels, which maintain their integrity for longer periods of time. Conversely, alginates rich in mannuronic acid residues develop softer, less porous gels that tend to disintegrate with time (Simpson et al., 2004; Reis et al., 2006).

Since Ca-alginate gel has a macroporous structure sensitive to the presence of non-gelling ions, such as sodium and magnesium, a membrane coat and/or a filling material can be applied to improve stability and decrease bead permeability (Ribeiro et al., 1999; Calija et al., 2011).

Alginate microparticles can be treated with a polycationic polymer, because electrostatic interaction of the alginate carboxyl groups with the polycationic polymer encloses the encapsulant, improving drug retention or release potential (Ribeiro et al., 1999; Calija et al., 2011). Polylysine and chitosan are the most commonly used polycation for capsule production, but DEAE - dextran has also been applied (Gaserod, Smidsrod, Skjak-Braek, 1998). 
Chitosan is a natural polymer produced mainly from the partial deacetylation of chitin, which occurs in the exoskeleton of crustaceans (Rowe, Sheskey, Quinn, 2009; Florczyk et al., 2011). It is composed of units of $\beta$ (1-4)- $D$-glucosamine and $\beta$ (1-4) $N$-acetyl$D$-glucosamine in variable proportions. Its functional properties depend on average molecular weight, degree of acetylation, load distribution and density, viscosity and $\mathrm{pH}$ of use (Canella, Garcia, 2001; Aranaz et al., 2009; Rowe, Sheskey, Quinn, 2009). Chitosan presents mucoadhesion, biocompatibility and biodegradability (Ribeiro et al., 1999; Wittaya-areeku, Kruenate, Prahsarn, 2006), having a hydrophilic nature and antibacterial activity (Florczyc et al., 2011).

Alginate-chitosan microparticles can be produced by a one-stage process, in which a complex coacervate membrane is formed when the alginate solution is dripped directly into a calcium chloride solution containing chitosan (Gaserod, Sannes, Skjak-Braek, 1999; Wittayaareeku, Kruenate, Prahsarn, 2006). The other method is the two-stage process comprising the primary production of Ca-alginate microparticles followed by a membrane forming step where the beads produced are suspended in a chitosan solution (Gaserod, Sannes, Skjak-Braek, 1999; Wittaya-areeku, Kruenate, Prahsarn, 2006).

The aim of this work was to improve the one-stage external ionic gelation technique to obtain microparticles of alginate-starch-chitosan containing stigmasterol dissolved in canola oil using natural biopolymers.

\section{MATERIAL AND METHODS}

\section{Material}

Sodium alginate (Protanal LF 20/40, FMC BioPolymer, U.S.A., with a viscosity of between 100 and $200 \mathrm{mPas}$ and $\mathrm{G}$ residue content between 65 and $75 \%$ ), corn starch (DEG, Brazil), Stigmasterol (Fluka, U.S.A., purity degree $\geq 90 \%$ ), Canola oil (Cargill, Brazil), Poloxamer 407 (Embrafarma, Brazil) and Chitosan (Galena, Brazil) were employed. All other chemicals and reagents used were of analytical grade.

\section{Purification of Chitosan}

Purification of chitosan was performed as described by Signini and Campana-Filho (1998). The polymer was suspended in acetic acid $0.5 \mathrm{M}$ solution and magnetically stirred for approximately 24 hours. The viscous solution was filtered through a $5 \cdot 10^{-3} \mathrm{~mm}$ glass fibre micro filter and a $0.22 \cdot 10^{-3} \mathrm{~mm}$ cellulose membrane (Millipore).
Concentrated $\mathrm{NH}_{4} \mathrm{OH}$ was added drop-wised to the filtrate for precipitation of chitosan. The polymer was filtered and rinsed with distilled water to $\mathrm{pH} 7.0$ followed by methanol. Chitosan was dried at $60{ }^{\circ} \mathrm{C}$ for 24 hours and kept in a desiccator over silica gel under vacuum for 2 hours. Chitosan was crushed and sieved to afford a 16-mesh powder.

\section{Characterization of chitosan}

\section{Average degree of deacetylation}

The average degree of deacetylation was determined by conductometric titration as described by Santos et al. (2003). Chitosan was solubilized in $\mathrm{HCl} 0.05 \mathrm{M}$ solution for 18 hours with constant stirring at room temperature. The chitosan solution was titrated with $\mathrm{NaOH} 0.17 \mathrm{M}$ solution and the conductance measurements $\left(\mu \mathrm{S} . \mathrm{cm}^{-1}\right)$ were performed using a PHTek CD 203 portable conductivity meter, under controlled temperature.

\section{Intrinsic viscosity}

The intrinsic viscosity was determined according to Signini and Campana-Filho (1998), by relating reduced viscosity versus chitosan at finite concentration, and extrapolating to infinite dilution. Chitosan was dissolved in a buffer solution $\mathrm{pH} 4.5$ of acetic acid $0.3 \mathrm{M}$ and sodium acetate $0.2 \mathrm{M}$, under constant agitation for 15 hours. The solution was heated in a water bath at $80^{\circ} \mathrm{C}$ for 2 minutes, cooled at room temperature and after adding a further $25 \mathrm{~mL}$ of buffer solution, was heated again to $80^{\circ} \mathrm{C}$ for 2 minutes. After cooling, the solution was filtered through a $0.22 .10^{-3} \mathrm{~mm}$ cellulose membrane. A solution with relative viscosity $(\mathrm{t} / \mathrm{t} 0)$ less than 1.8 was sequentially diluted by addition of the acetic acid-sodium acetate buffer solution until attaining a relative viscosity of around 1.2. The flow times were determined with a Cannon-Fenske capillary viscometer $(\varnothing=0.54 \mathrm{~mm})$, thermostated at $25^{\circ} \mathrm{C} \pm 0.1{ }^{\circ} \mathrm{C}$ on an AVS 350 system (Schott-Geräte). The values of the flow times represent the average of three independent determinations for each dilution.

\section{Preparation of microparticles}

Alginate-starch-chitosan microparticles were obtained through a one-stage process. A system was prepared by dispersing $20 \mathrm{~g}$ of canola oil containing 0.2 $\mathrm{g}$ of stigmasterol in $80 \mathrm{~g}$ of a sodium alginate aqueous solution $1.0 \%(\mathrm{w} / \mathrm{w})$ containing corn starch $0.3 \%$ $(\mathrm{w} / \mathrm{w})$ and poloxamer $4070.3 \%(\mathrm{w} / \mathrm{w})$. The raw material percentages refer to the final dispersion. Both phases were kept at $60^{\circ} \mathrm{C}$ during the dispersion and were spontaneously 
cooled while stirring at $800 \mathrm{rpm}$ for 15 minutes in a mechanical stirrer. The mixture was poured with a syringe into a $100 \mathrm{~mL}$ gelling bath, which contained $\mathrm{CaCl}_{2} 2.0 \%$ $(\mathrm{w} / \mathrm{v})$ and chitosan $0.5 \%(\mathrm{w} / \mathrm{v})$ previously dissolved in acetic acid $1.0 \%(\mathrm{v} / \mathrm{v})$.

The gelling bath $\left(\mathrm{CaCl}_{2} /\right.$ chitosan $)$ was maintained at $250 \mathrm{rpm}$ rotation in a magnetic stirrer at room temperature. The cross-linking time was 60 minutes. After this period, microparticles were washed twice with $200 \mathrm{ml}$ of $\mathrm{CaCl}_{2}$ $0.05 \mathrm{M}$ solution containing Tween ${ }^{\circledR} 801.0 \%(\mathrm{w} / \mathrm{v})$ and then vacuum filtered.

After removal of the excess water, the wet microparticles were weighed for later determination of residual moisture and particle size. Subsequently, some microparticles were dried in an air column until constant weight at $50{ }^{\circ} \mathrm{C}$ while others were lyophilized. The microparticles dried in the air column were weighed and prepared for the process of particle size measurement and determination of encapsulation efficiency.

\section{Characterization of microparticles}

\section{Morphology}

The morphology of the microparticles was observed under an optical microscope (Studarlab), and images were captured with an Olympus Stylus Tough 8000 digital camera and scanning electron microscopy (SEM) $(10,001$ Tabletop Phenom).

\section{Microencapsulation yield}

The microencapsulation yield was determined by the ratio of the total amount of raw material used in the process to the dry weight of the microparticles obtained.

\section{Determination of residual moisture}

The residual moisture was gravimetrically determined by loss on drying. The wet microparticles were weighed and dried in an air column at $50{ }^{\circ} \mathrm{C}$ for 30 minutes. The process was repeated until constant weight of the sample was reached. The residual moisture was expressed in percent according to the equation:

$$
M \%=\frac{\text { Initial weight }- \text { Final weight }}{\text { Initial weight }} \cdot 100
$$

\section{Particle size analysis}

The determination of particle size distribution of wet and dried microparticles was performed in triplicate, based on the method described in the Farmacopeia Brasileira V (2010).

For the analysis, sieves of $1.70 \mathrm{~mm} / 10 \mathrm{mesh}$,
$1.40 \mathrm{~mm} / 12 \mathrm{mesh}, 1.00 \mathrm{~mm} / 16 \mathrm{mesh}, 710 \mu \mathrm{m} / 24 \mathrm{mesh}$ were sequentially arranged. The wet microparticles were weighed and sieved with vertical and horizontal vibrating motions for 10 minutes. The microparticles retained by each sieve were weighed.

\section{Encapsulation efficiency}

Encapsulation efficiency was determined by extracting the encapsulated oil using the modified Bligh and Dyer method (Brum, Arruda, Reginato-d'Arce, 2009). Dried microparticles were placed in $80 \mathrm{~mL}$ sodium phosphate buffer solution $\mathrm{pH} 7.4$ for 12 hours. After this period, chloroform $100 \mathrm{~mL}$ and methanol $200 \mathrm{~mL}$ were added to phosphate buffer solution, forming a solvent system in the proportion $0.8: 1: 2(\mathrm{v} / \mathrm{v})$. The mixture was vigorously stirred and allowed to stand for 12 hours. A 60-mesh sieve was used to retain waste microparticles and the filtrate was transferred to a separatory funnel. Chloroform $100 \mathrm{~mL}$ and water $100 \mathrm{~mL}$ were added to the filtrate, so that the final solvent system reached the proportion of 1.8:2:2(v/v). The system was stirred and allowed to stand until complete phase separation. The chloroform/oil phase was separated and filtered through a funnel containing $\mathrm{Na}_{2} \mathrm{SO}_{4}$. The filtrate was kept at room temperature for solvent evaporation until constant oil weight. The ratio of the amount of encapsulated oil to the initial oil amount defines encapsulation efficiency (EE) and is expressed as a percentage (\%) according to the equation:

$$
E E \%=\frac{\text { Encapsulated oil }}{\text { Initial oil }} \cdot 100
$$

\section{Quantification of encapsulated stigmasterol}

\section{Analytical curve}

Stigmasterol standard solution $0.5 \mathrm{mg} / \mathrm{mL}$ was pipetted out into 5 test tubes containing $2 \mathrm{~mL}$ of canola oil diluted in chloroform 1:50 (w/v), labeled P1, P2, P3, $\mathrm{P} 4$ and $\mathrm{P} 5$ in order to obtain concentrations of 7.5, 8, 75, $10,11.25$ and $12.5 \mathrm{mg} / \mathrm{g}$. There were also two separate test tubes containing only $2 \mathrm{ml}$ of canola oil diluted in chloroform 1:50 (w/v) serving as blank and negative samples. Thus, $2 \mathrm{~mL}$ of the Liebermann-Burchard reagent, composed of $60 \mathrm{~mL}$ of acetic anhydride and $3 \mathrm{~mL}$ of sulfuric acid, were added to all samples, except the blank tubes, and the volume completed to $9 \mathrm{~mL}$ with chloroform. The samples remained at room temperature, protected from light for 15 minutes. After this period, concentrations were measured in a spectrophotometer at $640 \mathrm{~nm}$. The procedure was performed in triplicate. 
Quantification of stigmasterol by UV-VIS spectrophotometry

For the determination of encapsulated stigmasterol, $2 \mathrm{~mL}$ of Liebermann-Burchard reagent was added to $2 \mathrm{~mL}$ of oil extracted from the microparticles and diluted to 1:50 (w/v). The final volume was completed to $9 \mathrm{~mL}$ with chloroform and the samples stored protected from light at room temperature for 15 minutes. The presence of sterols produces a characteristic green color whose absorbance was measured in a spectrophotometer at $640 \mathrm{~nm}$ (Sabir et al., 2005; Jain, Bari, Surana, 2009; Daksha et al., 2010).

\section{RESULTS AND DISCUSSION}

\section{Purification of Chitosan}

Purification is an important process for obtaining uniform samples, free of insoluble contaminants and completely soluble, resulting in a polymer with suitable characteristics for the intended objectives (Signini, Campana-Filho, 1998).

Purified polymer minimally interferes in the biological systems and is suitable for use as a biomaterial (Abbas, 2010).

Purification methods may be performed using either hydrochloride or neutralized chitosan. In its neutralized form, purification is a process that requires less time, material and equipment and increases yield (Signini, Campana-Filho, 1998).

The procedure resulted in $78 \%$ yield of recovered material, in the form of fine pale brown crystalline flakes, totally soluble in acidic solutions such as acetic acid and hydrochloric acid.

\section{Characterization of chitosan}

\section{Average degree of deacetylation}

Average degree of deacetylation of Chitosan is defined as the number of amine groups related to the amide groups of the polymer chain (Santos et al., 2003). A high degree of deacetylation is preferable for interaction with alginate guluronic acid residues (Rowe, Sheskey, Quinn, 2009).

The values of conductance with the corresponding titrant volumes were plotted on a graph to find the linear variation before and after the equivalence point. Three line segments were observed. The first rapid descending branch corresponds to neutralization of $\mathrm{HCl}$ in excess, the second segment depicts neutralization of the amine group and the third indicates the excess of base. The two stoichiometry points are found by taking the intersection of the three lines, where the difference between the two points corresponds to the volume of the base required to neutralize the amine groups (Santos et al., 2003; Rinaudo, 2006).

The average degree of deacetylation (DD) is calculated using the equation:

$$
D D \%=\frac{[\text { base }] \cdot\left(V_{1}-V_{2}\right) \cdot 161}{M} \cdot 100
$$

where DD is the average degree of deacetylation, $\mathrm{V}_{1}$ and $\mathrm{V}_{2}$ are the volume of $\mathrm{NaOH}$ (in $\mathrm{mL}$ ) used in the titration, [base] is the concentration of $\mathrm{NaOH}, \mathrm{M}$ is the mass of chitosan (in mg) and 161 is the molar mass of the monomer (Santos, Cirilo, Nunes, 2011).

Under the conditions set, the average degree of deacetylation of the sample was $84.54 \%$.

\section{Intrinsic viscosity}

The solubilization of a polymer in a solvent is a very important feature in the viscosimetry process. This depends on the concentration, molecular weight and chain conformation, and the most suitable conditions for polymer solubilization. To avoid poor solubilization of the samples or formation of clusters, the method was performed with a solvent system of acetic acid $0.3 \mathrm{M} /$ sodium acetate $0.2 \mathrm{M}$, pH 4.5, proposed by Rinaudo (2006).

The intrinsic viscosity [ $\eta]$ was calculated graphically by extrapolating the curve of reduced viscosity versus concentration to zero concentration. The correlation coefficient $\mathrm{R}^{2}$ between the experimental points was 0.9951 and the straight-line equation expressed by $\mathrm{y}=31.606 \mathrm{x}$ +274.51 . Chitosan intrinsic viscosity $[\eta]$ when $(\mathrm{C} \rightarrow 0)$ is $274.51 \mathrm{~mL} / \mathrm{g}$.

The chitosan molecular weight was then calculated by the Mark-Houwink equation:

$$
[\eta]=K_{H} \cdot M_{w} \cdot \alpha
$$

where $K_{H}$ is the Huggins constant, a characteristic of the polymer, which depends on temperature, solvent system used and degree of acetylation, $\alpha$ is the characteristic constant of the geometry of the polymer molecule and $\mathrm{Mw}$ (g.mol ${ }^{-1}$ ) is the viscosimetric molar weight. The values of the viscosimetric constants were drawn from the literature (Battisti, Campana-Filho, 2008).

Based on the values of the constants $\mathrm{K}_{\mathrm{H}}(0.075)$, $\alpha(0.76)$ and intrinsic viscosity (274.51), the chitosan viscosimetric molecular weight (Mv) was 48,829 Da.

Chitosan molecular weight affects both the index and extent of linkage in the alginate microparticles. 
The lower molecular weight chitosans (20,000 Da) are uniformly distributed over the whole particle, causing a significant decrease in interaction between the polymers with the increase in acetyl groups. High molecular weight chitosans are mainly accumulated on the surface because they are too large to enter into the pores (Gaserod, Smidsrod, Skjak-Braek, 1998).

\section{Production and characterization of alginate- starch-chitosan microparticles}

\section{Microparticle production}

During sample preparation, special care was taken to minimize artefact formation and further reactions of sterol oxides, because sterol oxides are less stable than sterols. Thus, high temperatures, light and oxygen were avoided (Piironen et al., 2000).

Among the common vegetable oils, rapeseed and canola oils are considered a good convenient source of phytosterols. Brassicasterol, $\beta$-sitosterol and campesterol together account for $80-88 \%$ of total sterols. Cholesterol, campesterol, $\Delta 5$-avenasterol, $\Delta 7$ sigmastenol, 24-methylene cholesterol, campestanol, $\Delta 5,23$-stigmastadiene, sitostanol, $\Delta 5,24$-stigmastenol and $\Delta 7$-avenasterol are also present in rapeseed and canola oil but at lower levels. Stigmasterol is a major sterol in most common vegetable oil. However, it is a minor component in rapeseed and canola oil. Typically it does not exceed $1 \%$ of total sterols (Gunstone, 2004).

Canola oil was used in this work because of its low stigmasterol content and high level of sterols. In addition, some studies have demonstrated the influence of lipid matrices, including canola oil, for decreasing the oxidation process (Lampi et al., 2002).

Researchers have found a correlation between degree of saturation of the lipid matrix and sterol oxidation rate (Otaegui-Arrazola et al., 2010). However, studies on the effects of co-oxidizing matrix lipids are controversial because some indicate that sterol oxidation is enhanced by unsaturated lipids, while others have shown that oxidation is more marked in saturated than in unsaturated lipid matrices (Lampi et al., 2002).

A study of thermo-oxidation of sterols was carried out in stigmasterol and rapeseed oil. Both substances were heated at $180 \pm 5{ }^{\circ} \mathrm{C}$ for up to 6 and 24 hours, respectively. Thermo-oxidation of sterols was slower in rapeseed oil than bulk stigmasterol. The result indicates that this oxidation, akin to autoxidation, is significantly dependent on the sample area subjected to air and the area to volume ratio, which were much larger in the bulk stigmasterol than in the rapeseed oil samples. Moreover, the profile of products was more stable in rapeseed oil than in stigmasterol where further reactions of oxidation products occurred (Lampi et al., 2002).

The microencapsulation technique can be used to minimize the oxidation process. Accelerated stability testing was performed by Oliveira (2007) using microencapsulated stigmasterol and a stigmasterol standard solution. The presence of oxidation products after 60 days was confirmed in both the stigmasterol standard solution and the stigmasterol encapsulated with stearic acid. The latter showed a lower amount of oxidation products. Stigmasterol encapsulated with gelatin showed no formation of oxidation products.

Some encapsulation methods involve the use of organic solvents or other reagents and high temperatures to achieve the same goal, however, these conditions can be incompatible with many biological encapsulants, such as plant cells, mammalian cells, yeasts, bacteria, insulin, magnetite or food products such as edible oils (Poncelet et al., 1992; Fundueanu et al., 1999).

The use of various gel-forming proteins (collagen and gelatin) and polysaccharides (agar, calcium alginate and carrageenan) has resulted in milder, biocompatible immobilization techniques (Poncelet et al., 1992).

In this context, the external ionic gelation technique for microencapsulation of stigmasterol was chosen due to the milder process, without the use of organic solvents and high temperatures.

Between the two most common methods of external ionic gelification to obtain alginate-starch-chitosan microparticles, the one-stage process was chosen because it allows the formation of less permeable microparticles, due to the different ways of forming the alginate-chitosan complex. While the alginate is in gel form in the twostage process, the membrane in the one-stage process is formed when both polymers are in solution, leading to the formation of particles with small pores. These resulting small pores are probably the reason why these capsules bind small amounts of chitosan as they restrict their diffusion into the matrix (Gaserod, Smidsrod, SkjakBraek, 1998; Gaserod, Sannes, Skjak-Braek, 1999).

The presence of starch in the formulation provided the microparticles with greater stability during the drying process, since the suitable mixtures of polymers consist of convenient and effective methods of improving the performance of polymeric materials. Previous studies have demonstrated that intermolecular interactions and good molecular compatibility occur between starch and alginate (Wang et al., 2010). The ratio of alginate:starch was 1:0.3 (w/w), because larger proportions can damage the alginate-chitosan cross-linking by competing in the 
interpolymer interactions, leading to a failed or incomplete alginate-chitosan complex.

The use of poloxamer 407, a nonionic dispersing agent with a hydrophile-lipophile balance (HLB) of between 18 and 23, allows for the proper dispersion of the oil phase over the aqueous phase of the system, avoiding nucleation and poor distribution of oil, thus contributing to the encapsulation efficiency of the drug (Zanin et al., 2002; Culpi et al., 2010).

\section{Drying process}

Two drying processes have been tested, lyophilization and the air column. In the first case microparticles showed morphological changes (Figure 1a and $1 \mathrm{~b}$ ) even in the presence of starch as the filling material, while the second process maintained their spherical shape (Figure 1c and 1d). Chan et al. (2011) argued that when microparticles are lyophilized, they tend to exhibit different sizes, fragility in their mechanical structure and high porosity, factors that influence the stability of the encapsulated substance. The use of starch as a filling material can improve these characteristics, maintaining the spherical shape and decreasing the shrinkage of the microparticles.

\section{Product yield}

The average yield of microparticles was $94.87 \%$ in relation to the raw material used.
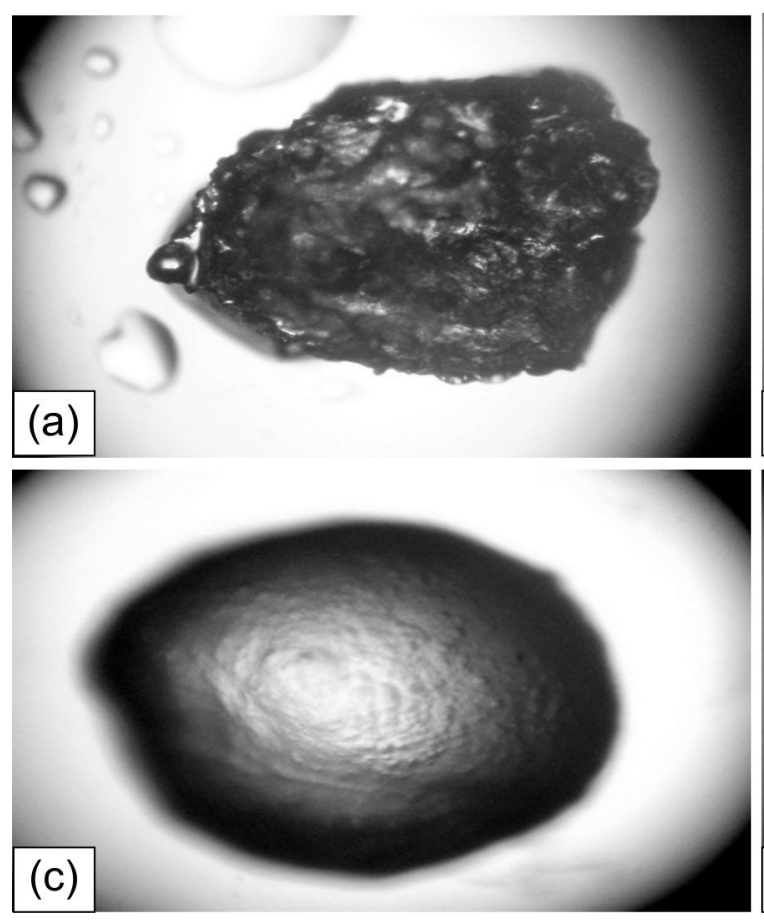

Morphology, residual moisture and particle size

The microparticles were spherical, slightly oval, with average residual moisture of $60.59 \%$. In the wet microparticle size analysis, $98.40 \%$ were retained by a 10 -mesh sieve, and after drying process, $71 \%$ were retained by a 12 -mesh sieve.

\section{Encapsulation efficiency}

For oil content determination in the microparticles, some studies report the use of organic solvents such as hexane, chloroform and carbon tetrachloride for oil extraction (Peniche et al., 2004, Tan, Chan, Heng, 2009). Another method employed consists of the disruption of the microparticles by the use of a $\mathrm{pH} 7.4$ sodium phosphate buffer solution or sodium citrate buffer solution $0.055 \mathrm{M}$ to remove the $\mathrm{Ca}^{+2}$ ions from the microparticles. This process causes destabilization of the three-dimensional network and releases the oil to the medium making it available for dissolution in an organic solvent and for quantification after solvent evaporation (Ribeiro et al., 1999).

In previous studies, our group has tested oil extraction by using organic solvents including chloroform and hexane, the phosphate buffer solution procedure and the Bligh and Dyer method, with a solvent system of chloroform: methanol: water ratio of 1:2:0.8 (v/v). In the first case, the absence of oil droplets within the microparticles under an optical microscope was observed.

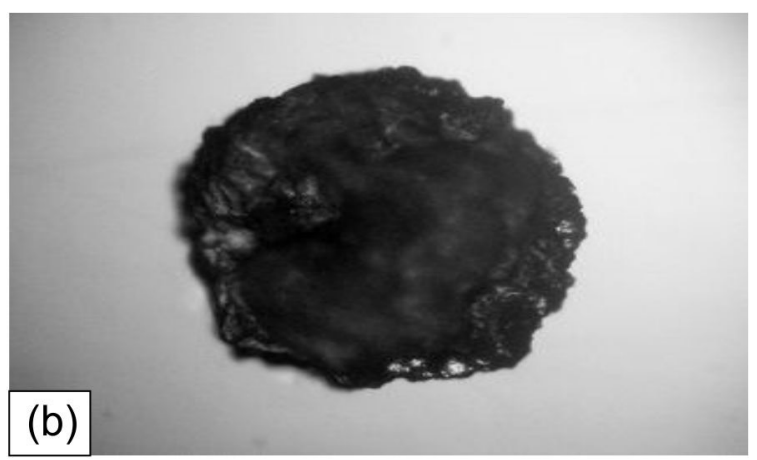

FIGURE 1 - (a) Lyophilized microparticles without starch; (b) Lyophilized microparticles with starch; (c) Microparticles without starch dried in air column (d) Microparticles with starch dried in air column at mo (40x). SOURCE: The author (2011). 
Nevertheless, at the end of the process, the residues from the microparticles were found to be oily, suggesting the presence of oil in the residues. The same result was obtained using the microparticle disruption method in phosphate buffer solution $\mathrm{pH}$ 7.4. Therefore, it was decided to work with the Bligh and Dyer method. The microparticles were left in contact with the solvent mixture for 12 hours, with periodic agitation. After this period, it was verified that the standard method was unable to extract all the oil from the microparticles, and thus required some adaptation.

A modified Bligh and Dyer method was then performed. Initially, a phosphate buffer solution $\mathrm{pH} 7.4$ was used instead of water for membrane destabilization. After this first stage, chloroform and methanol were added to the mixture, maintaining the proportion suggested by Bligh and Dyer (1:2:0.8). At the end of the extraction process, no oil was present in the waste of microparticles.

This technique presented an average encapsulation efficiency (EE) of $90.42 \%$.

\section{Quantification of stigmasterol by UV-VIS spectrophotometry}

The main advantages of UV-VIS spectrophotometry include ease of operation, good sensitivity and accuracy, moderate selectivity and wide applicability (Gil, 2007).

The Liebermann-Burchard reaction used for determination of steroids or other sterols (natural sterols are crystalline 3-hydroxy-steroids containing an aliphatic side chain) comprises a reaction in a mixture of acetanhydride and a relatively small amount of sulfuric acid (Burke et al., 1974; Xiong, Wilson, Pang, 2007).

Sterols react with various strong acids to give colored products, and although these reactions have been used empirically for many years for the qualitative and quantitative determination of sterols, their underlying mechanisms are not yet clearly understood (Burke et al., 1974).

The linearity of the method was established using stigmasterol standard solution. The analytical curve showed a Pearson regression coefficient $\left(\mathrm{R}^{2}\right)$ of 0.9989 and standard deviation of less than $5.0 \%$. The analysis of variance for each standard concentration was performed by the SISVAR program (Ferreira, 2000) and no statistically significant difference was found on Tukey's test $(p<0.05)$.

Three batches of microparticles were analyzed in triplicate for quantification of stigmasterol--showing a standard deviation of less than 5.0\%--whose final average stigmasterol concentration was $9.97 \mathrm{mg} / \mathrm{g}$ compared to the initial concentration of $10.00 \mathrm{mg} / \mathrm{g}$ (per gram of oil).

\section{CONCLUSION}

Alginate-starch-chitosan microparticles containing stigmasterol solubilized in canola oil were successfully produced by the one-stage external ionic gelation method. Canola oil, in which stigmasterol is dissolved, has an important role in decreasing oxidation product formation. Alginate is well suited to form the matrix for the microencapsulation of various substances such as sterols and edible oils. Since alginate gels have a porous structure, a filling material such as starch and a chitosan membrane coat was applied to provide stability and reduce bead permeability. External ionic gelation using an alginate-starch-chitosan blend as a wall material potentially has widespread applications due to its easy and mild production, relatively high encapsulation efficiency and oxidative protection. The resultant microparticles are spherical, uniform, and slightly rough on the surface, with an average size of $1.4 \mathrm{~mm}$. A production yield of $94.87 \%$ and encapsulation efficiency of $90.42 \%$ was obtained by this easy-to-perform method.

\section{REFERENCES}

ABBAS, O.M. Chitosan for biomedical applications. Iowa, 2010. $329 \mathrm{f}$. [Thesis of PhD degree. Faculty of Pharmaceutical Sciences. University of Iowa].

ARANAZ, I.; MENGÍBAR, M.; HARRIS, R.; PAÑOS, I.; MIRALLES, B.; ACOSTA, N.; GALED, G.; HERAS, A. Functional characterization of chitin and chitosan. Curr. Chem. Biology, v.3, n.2, p.203-230, 2009.

BATTISTI, M.V.; CAMPANA-FILHO, S.P. Obtenção e caracterização de $\alpha$-quitina e quitosanas de cascas de Macrobrachium rosembergii. Quím. Nova, v.31, n.8, p.2014-2019, 2008.

BROOKS, C.J.W. Steroids: sterols and bile acids. In: COFFEY, S. Rodd's chemistry of carbon compounds: a modern comprehensive treatise. Steroids. 2.ed. Elservier, 1970. v.2, part.4, 500p.

BRUFAU, G.; CANELA, M.A.; RAFECAS, M. Phytosterols: physiologic and metabolic aspects related to cholesterollowering properties. Nutr. Res., v.28, n.4, p.217-225, 2008.

BRUM, A.A.S.; ARRUDA, L.F.; REGINATO-d'ARCE, M.A.B. Métodos de extração e qualidade da fração lipídica de matérias-primas de origem vegetal e animal. Quím. Nova, v.32, n.4, p.849-854, 2009. 
BURKE, R.W.; DIAMONDSTONE, B.I.; VELAPOLDI, R.A.; MENIS, O. Mechanisms of the Liebermann-Burchard and Zak color reactions for cholesterol. Clin. Chem., v.20, n.7, p.794-801, 1974.

CALIJA, B.; CEKIC, N.; SAVIC, S.; KRAJISNIK, D.; DANIELS, R.; MILIC, J. An investigation of formulation factors affecting feasibility of alginate-chitosan microparticles for oral delivery of naproxen. Arch. Pharmacol. Res., v.34, n.6, p.919-929, 2011.

CANELLA, K.M.N.C.; GARCIA, R.B. Caracterização de quitosana por cromatografia de permeação em gel: influência do método de preparação e do solvente. Quím. Nova, v.24, n.1, p.13-17, 2001.

CHAN, E.S. Preparation of Ca-alginate beads containing high oil content: influence of process variables on encapsulation efficiency and bead properties. Carbohydr. Polym., v.84, n.4, p.1267-1275, 2011.

CHAN, L.W.; LIM, L.T.; HENG, P.W.S. Microencapsulation of oils using sodium alginate. J. Microencapsulation, v.17, n.6, p.757-766, 2000.

CHAN, E.S.; WONG, S.L.; LEE, P.P.; LEE, J.S.; TI, T.B.; ZHANG, Z.; PONCELET, D.; RAVINDRA, P.; PHAN, S.H.; YIM, Z.H. Effects of starch filler on the physical properties of lyophilized calcium-alginate beads and the viability of encapsulated cells. Carbohydr. Polym., v.83, n.1, p.225-232, 2011.

CULPI, T.A.; PASQUALIM, P.; FIN, M.T.; SASSO, D.G.B.; KAMINSKI, G.A.T.; FUJIWARA, G.M.; NUNES, P.M.P.; RODRIGUES, B.H.; DIAS, J.F.G.; ZANIN, S.M.W. Importância de parâmetros de controle na elaboração de micropartículas de $\mathrm{Ca}^{2+}$ - alginato. Visão Acadêmica, v.11, n.1, p.38-44, 2010.

DAKSHA, A.; JAYWANT, P.; BHAGYASHREE, C.; SUBODH, P. Estimation of sterols content in edible oil ande ghee samples. Electron. J. Environ. Agric. Food Chem., v.9, n.10, p.1593-1597, 2010.

FARMACOPEIA BRASILEIRA. 5.ed. Brasília: Agência Nacional de Vigilância Sanitária, 2010. v.1. 545p.

FERNANDES, P.; CABRAL, J.M.S. Phytosterols: applications and recovery methods. Bioresour. Technol., v.98, n.12, p.2335-2350, 2007.
FERREIRA, D.F. Sistema de análises de variância para dados balanceados. Lavras: UFLA, 2000. 1 CD-ROM. SISVAR 4.

FLORCZYK, S.J.; KIM, D.; WOOD, D.L.; ZHANG, M. Influence of processing parameters on pore structure of $3 \mathrm{D}$ porous chitosan-alginate polyelectrolyte complex scaffolds. J. Biomed. Mater. Res. A, v.98, n.4, p.614-620, 2011.

FOLEY, D.; O'CALLAGHAN, Y.; O'BRIEN, N.M.; McCARTHY, F.O.; MAGUIRE, A.R. Synthesis and characterization of stigmasterol oxidation products. $J$. Agric. Food Chem., v.58, n.2, p.1165-1173, 2010.

FUNDUEANU, G.; NASTRUZZI, C.; CARPOV, A.; DESBRIERES, J.; RINAUDO, M. Physico-chemical characterization of Ca-alginate microparticles produced with different methods. Biomaterials, v.20, n.15, p.1427$1435,1999$.

GABAY, O.; SANCHEZ, C.; SALVAT, C.; CHEVY, F.; BRETON, M.; NOURISSAT, G.; WOLF, C.; JACQUES, C.; BERENBAUM, F. Stigmasterol: a phytosterol with potential anti-osteoarthritic properties. Osteoarthr. Cartilage, v.18, n.1, p.106-116, 2010.

GARCÍA-LATTAS, G.; RODRÍGUEZ-ESTRADA, M.T. Current and new insights on phytosterol oxides in plant sterol-enriched food. Chem. Phys. Lipids, v.164, n.6, p.607$624,2011$.

GASEROD, O.; SMIDSROD, O.; SKJAK-BRAEK, G. Microcapsules of alginate-chitosan. I. A quantitative study of the interaction between alginate and chitosan. Biomaterials, v.19, n.20, p.1815-1825, 1998.

GASEROD, O.; SANNES, A.; SKJAK-BRAEK, G. Microcapsules of alginate-chitosan. II. A study of capsule stability and permeability. Biomaterials, v.20, n.8, p.773$783,1999$.

GIL, E.S. Controle fisico-químico de qualidade de medicamentos. 2.ed. São Paulo: Pharmabooks, 2007. 485 p.

GÓMEZ, M.A.; SAENZ, M.T.; GARCÍA, M.D.; FERNANDEZ, M.A. Study of the topical anti-inflammatory activity of Achillea ageratum on chronic and acute inflammation models. Z. Naturforsch., v.54c, n.11, p.937-941, 1999.

GUNSTONE, F.D. Rapeseed and canola oil: production, processing, properties and uses. 2.ed. Boca Raton: Blackwell Publishing - CRC Press, 2004. 222 p. 
IFERE, G.O.; BARR, E.; EQUAN, A.; GORDON, K.; SINGH, U.P.; CHAUDHARY, J.; IGIETSEME, J.U.; ANANABA, G.A. Differential effects of cholesterol and phytosterols on cell proliferation, apoptosis and expression of a prostate specific gene in prostate cancer cell lines. Cancer Detect. Prev., v.32, n.4, p.319-328, 2009.

JAIN, P.S.; BARI, S.B.; SURANA, S.J. Isolation of stigmasterol and $\gamma$-sitosterol form petroleum ether extract of woody stem of Abelmoschus manihot. Asian J. Biol. Sci., v.2, n.4, p.112-117, 2009.

JYOTHI, N.V.N.; PRASANNA, P.M.; SAKARKAR, S.N.; PRABHA, K.S.; RAMAIAH, P.S.; SRAWAN, G.Y. Microencapsulation techniques, factors influencing encapsulation efficiency. J. Microencapsulation, v.27, n.3, p.187-197, 2010.

LAMPI, A.M.; JUNTUNEN, L.; TOIVO, J. PIIRONEN, V. Determination of thermooxidation products of plant sterols. J. Chromatogr. B, v.777, n.1-2, p.93-92, 2002.

LEE, H.Y.; CHAN, L.W.; DOLZHENKO, A.V.; HENG, P.W.S. Influence of viscosity and uronic acid composition of alginates on the properties of alginate films and microspheres produced by emulsification. J. Microencapsulation, v.23, n.8, p.192-927, 2006.

MARANGONI, F.; POLI, A. Phytosterols and cardiovascular health. Pharmacol. Res., v.61, n.3, p.193-196, 2010.

MOGHADASIAN, M.H. Pharmacological properties of plant sterols: in vivo and in vitro observations. Life Sci., v.67, n.6, p.605-615, 2000.

NÓRMEN, A.L.; BRANTS, H.A.M.; VOORRIPS, L.E.; ANDERSSON, H.A.; VAN DEN BRANDT, P.A.; GOLDBOHM, R.A. Plant sterol intakes and colorectal cancer risk in the netherlands cohort study on diet and cancer. Am. J. Clin. Nutr., v.74, n.1, p.141-148, 2001.

OLIVEIRA, A.B. Microencapsulamento de estigmasterol proveniente de musa paradisíaca L., Musaceae. Curitiba, 2007. 112 f. [Dissertion of master degree. Department of Pharmacy Federal University of Paraná].

OTAEGUI-ARRAZOLA, A.; MENÉNDEZ-CARREÑO, M.; ANSORENA, D.; ASTIASARÁN, I. Oxysterols: a world to explore. Food Chem. Toxicol., v.48, n.2, p.3289-3303, 2010.
PANDA, S.; JAFRI, M.; KAR, A.; MEHETA, B.K. Thyroid inhibitory, antiperoxidative and hypoglycemic effects of stigmasterol isolated from Butea monosperma. Fitoterapia, v.80, n.2, p.123-126, 2009.

PENICHE, C.; HOWLAND, I.; CARRILLO, O.; ZALDÍVAR, C.; ARGÜELLES-MONAL, W. Formation and stability of shark liver oil loaded chitosan/calcium alginate capsules. Food Hydrocolloid, v.18, n.5, p.865-871, 2004.

PEREIRA, M.R.; CRUZ, L.; RÉ, M.I.; GUTERRES, S.S. Micropartículas secas contendo fármaco modelo lipofílico preparadas a partir de suspensão aquosa: estudo de formulação. Acta Farm. Bonaer., v.25, n.2, p.198-205, 2006.

PIIRONEN, V.; LIDSAY, D.G.; MIETTINEN, T.A.; TOIVO, J.I.; LAMPI, A.M. Plant sterols: biosynthesis, biological function and their importance to human nutrition. J. Sci. of Food Agric., v.80, n.7, p.939-966, 2000.

PONCELET, D.; LENCKI, R.; BEAULIEU, C.; HALLE, J.P.; NEUFELD, R.J.; FOURNIER, A. Production of alginate beads by emulsification/internal gelation. 1. Methodology. Appl. Microbiol. Biotechnol., v.38, n.1, p.39-45, 1992.

PONCELET, D. Microencapsulation: fundamentals, methods and applications. Surf. Chem. Biomed. Environ. Sci., v.228, part.1, p.23-34, 2006.

REIS, C.P.; NEUFELD, R.J.; VILELA, S.; RIBEIRO, A.J.; VEIGA, F. Review and current status of emulsion/ dispersion technology using na internal gelation process for the design of alginates particles. J. Microencapsulation, v.23, n.3, p.245-257, 2006.

RIBEIRO, A.J.; NEUFELD, R.J.; ARNAUD, P.; CHAUMEIL, J.C. Microencapsulation of lipophilic drugs in chitosancoated alginate microspheres. Int. J. Pharm., v.187, n.1, p.115-123, 1999.

RINAUDO, M. Chitin and chitosan: properties and applications. Prog. Polym. Sci., v.31, n.7, p.603-632, 2006.

ROWE, R.C.; SHESKEY, P.J.; QUINN, M.E. Handbook of pharmaceutical excipients. 6.ed. Londres: Pharmaceutical Press, 2009. 888 p.

RUDZINSKA, M.; KORCZAK, J.; GRAMZA, A.; WASOWICZ, E. Inhibition of stigmasterol oxidation by antioxidants in purified sunflower oil. J. AOAC Int., v.87, n.2, p.499-504, 2004. 
SABIR, S.M.; MAQSOOD, H.; HAYAT, I.; KHAN, M.Q.; KHALIQ, A. Elemental and nutritional analysis of sea Buckthorn (Hippophae rhamnoides ssp. turkestanica) berries of Pakistani origin. J. Med. Food, v.8, n.4, p.518$522,2005$.

SANTOS, A.R.S.; NIERO, R.; CECHINEL FILHO, V.; YUNES, R.A.; PIZZOLATTI, M.G.; DELLE MONACHE, F.; CALIXTO, J.B. Antinociceptive properties of steroids isolated from Phyllanthus corcovadensis in mice. Planta Med., v.61, n.4, p.329-332, 1995.

SANTOS, M.C.; CIRILO, A.T.O.; NUNES, M.L. Determinação do grau de desacetilação de quitosana obtida de camarão "Saburica" (Macrobrachium jelskii, Miers, 1877). Scientia Plena, v.7, n.9, p.1-4, 2011.

SANTOS, J.E.; SOARES, J.P.; DOCKAL, E.R.; CAMPANA FILHO, S.P.; CAVALHEIRO, E.T.G. Caracterização de quitosanas comerciais de diferentes origens. Polímeros: ciência e tecnologia, v.13, n.4, p.242-249, 2003.

SÄYNÄJOKI, S.; SUNDBERG, S.; SOUPAS, L.; LAMPI, A.M.; PIIRONEN, V. Determination of stigmasterol primary oxidation products by high-performance liquid chromatography. Food Chem., v.80, n.3, p.415-421, 2003.

SCHOUBBEN, A.; BLASI, P.; GIOVAGNOLI, S.; ROSSI, C.; RICCI, M. Development of a scalable procedure for fine calcium alginate particle preparation. Chem. Eng. J., v.160, n.1, p.363-369, 2010.

SEGATO, M.P. Estudos termoanalíticos do ácido algínico e dos alginatos de metais alcalinos, alcalinos-terrosos, amônio, mono-, di-, trietanolamônio. São Carlos, 2007. $112 \mathrm{f}$. [Dissertion of master degree. Institute of Chemistry of São Carlos. University of São Paulo].

SIGNINI, R.; CAMPANA-FILHO, S.P. Purificação e caracterização de quitosana comercial. Polímeros, v. 8 , n.4, p.63-68, 1998.

SIMPSON, N.E.; STABLER, C.L.; SIMPSON, C.P.; SAMBANIS, A.; CONSTANTINIDIS, I. The role of the $\mathrm{CaCl}_{2}$-guluronic acid interaction on alginate encapsulated $\beta$ TC3 cells. Biomaterials, v.25, n.13, p.2603-2610, 2004.
TAN, L.H.; CHAN, L.W.; HENG, P.W.S. Alginate/starch composites as wall material to achieve microencapsulation with high oil loading. J. Microencapsulation, v.26, n.3, p.263-271, 2009.

THU, B.; BRUHEIM, P.; ESPEVIK, T.; SMIDSROD, O.; SOON-SHIONG, P.; SKJAK-BRAEK, G. Alginate polycation microcapsules II. Some functional properties. Biomaterials, v.17, n.11, p.1069-1079, 1996.

TU, J.; BOLLA, S.; BARR, J.; MIEDEMA, J.; LI, X.; JASTI, B. Alginate microparticles prepared by spraycoagulation method: preparation, drug loading and release characterization. Int. J. Pharm., v.303, n.1, p.171-181, 2005.

VELASCO, J.; DOBARGANES, M.C.; MÁRQUEZ-RUIZ, G. Oxidation of free and encapsulated oil fractions in dried microencapsulated fish oils. Grasas Aceites, v.51, n.6, p.439-446, 2000.

XIONG, Q.; WILSON, W.K.; PANG, J. The liebermannburchard reaction: sulfonation, desaturation, and rearrangment of cholesterol in Acid. Lipids, v.42, n.1, p.87-96, 2007.

ZANIN, S.M.W.; MIGUEL, M.D.; CHIMELLI, M.C.; OLIVEIRA, A.B. Determinação do equilíbrio hidrófilolipófilo (EHL) de óleos de origem vegetal. Visão Acadêmica, v.3, n.1, p.13-18, 2002.

WALL, M.E.; KELLEY, E.G. Determination and nature of leaf sterols. Anal. Chem., v.19, n.9, p.677-683, 1947.

WANG, Q.; HU, X.; DU, Y.; KENNEDY, J. Alginate/starch blend fibers and their properties for drug controlled release. Carbohydr. Polym., v.82, p.842-847, 2010.

WITTAYA-AREEKUL, S.; KRUENATE, J.; PRAHSARN, C. Preparation and in vitro evaluation of mucoadhesive properties of alginate/chitosan microparticles containing prednisolone. Int. J. Pharm., v.312, n.3, p.113-118, 2006.

Received for publication on $09^{\text {th }}$ August 2012 Accepted for publication on $16^{\text {th }}$ April 2013 